\title{
Hyperleptinemia and leptin receptor variant Asp600Asn in the obese, hyperinsulinemic KK mouse strain
}

\section{Igel, B A Taylor ${ }^{1}$, S J Phillips ${ }^{1}$, W Becker, L Herberg ${ }^{2}$ and H-G Joost}

Institut für Pharmakologie und Toxikologie, Aachen, Germany

${ }^{1}$ The Jackson Laboratory, Bar Harbor, Maine, USA

${ }^{2}$ Diabetesforschungsinstitut, Düsseldorf, Germany

(Requests for offprints should be addressed to H G Joost, Institut für Pharmakologie und Toxikologie, Medizinische Fakultät der RWTH Aachen, Wendlingweg 2, D-52057 Aachen, Germany)

\begin{abstract}
KK obese mice exhibit a multigenic syndrome of moderate obesity, hyperinsulinemia and hyperglycemia. Here we show that the syndrome is accompanied by a marked elevation of leptin protein in adipose tissue, as well as leptin levels in serum, which corresponds with the degree of obesity. The cDNA sequence of leptin is normal in KK mice, whereas three nucleotide polymorphisms were found in the cDNA of the leptin receptor, one of them resulting in exchange of an aspartate residue for asparagine (Asp600Asn) in a highly conserved part of the second extracellular cytokine-receptor
\end{abstract}

homology module. In female (but not male) F2 mice of a $\mathrm{C} 57 \mathrm{BL} / 6 \mathrm{~J} \times \mathrm{KK}$ intercross, the weight of gonadal, retroperitoneal and mesenteric adipose tissue was positively correlated with the number of alleles inherited from the KK parental strain at a microsatellite marker (D4Mit175) which maps close $(0.7$ centimorgan proximal) to the leptin receptor gene. It is suggested that the Asp600Asn leptin receptor variant contributes to the obesity syndrome in KK female mice, but that its contribution is only a part of the multigenic syndrome.

Fournal of Molecular Endocrinology (1998) 21, 337-345

\section{INTRODUCTION}

KK mice exhibit a multigenic syndrome of moderate obesity, hyperinsulinemia and hyperglycemia (Kondo et al. 1957, Nakamura \& Yamada 1967). Insulin resistance appears similar to that observed in young diabetes mutant mice on the C57BLKS/J background (C57BLKS/J-Lepr ${ }^{d b}$ / $L e p r^{d b}$ (Lepr=leptin receptor); previous nomenclature: C57BLKS/J-db/db), whereas the degree of obesity is clearly lower (Herberg \& Coleman 1977). Recently, it was shown that obesity of the KK mouse is paralleled by a marked increase in the expression of leptin mRNA in adipose tissue (Igel et al. 1996b). This finding suggested the possibility that an aberrant leptin protein, or resistance to leptin, contributes to the development of obesity and insulin resistance.

Adipose tissue controls food intake by synthesis and secretion of a hormone, leptin, which stimulates a hypothalamic receptor (Zhang et al. 1994, Campfield et al. 1996, Friedman 1997). In the mouse mutants C57BL/6J-Lep $p^{o b} / L e p^{o b}$ (Lep=leptin; previous nomenclature: $\mathrm{C} 57 \mathrm{BL} / 6 \mathrm{~J}-o b / o b)$ and C57BLKS/J-Lepr ${ }^{d b} / L e p r^{d b}$, and in the obese Zucker rat $\left(\operatorname{Lepr}^{f a} / \operatorname{Lepr}^{f a}\right.$; previous nomenclature $\left.f a / f a\right)$, lack of leptin or a defective leptin receptor is responsible for excessive overeating, obesity, insulin resistance, cold intolerance and infertility (Chen et al. 1996, Chua et al. 1996b, Lee et al. 1996, Phillips et al. 1996). Furthermore, it has been shown that recombinant leptin reduces food intake and normalizes thermogenesis when given to $L e p^{o b} / L e p^{o b}$ mice (Campfield et al. 1995, Halaas et al. 1995, Pelleymounter et al. 1995).

As in the monogenic mutants Lep $p^{o b} / L e p^{o b}$ (Zhang et al. 1994) and Lepr ${ }^{d b} /$ Lepr $^{d b}$ (Maffei et al. 1995), increased levels of leptin mRNA have been found in several multigenic animal models of obesity, e.g. the mildly obese Sprague-Dawley rat (Igel et al. 1996b), the Otsuka Long Evans Tokushima fatty rat (Murakami \& Shima 1995), the New Zealand Obese mouse and the KK mouse (Igel et al. 1996b, 1997). These findings suggest that defects in the regulatory 
loop connecting adipose tissue and food intake are a common feature of obesity. In the present paper we have therefore characterized the KK mouse with respect to the levels of leptin in adipose tissue and serum, and to the cDNA sequence of leptin and its receptor. The results demonstrate hyperleptinemia and the presence of a leptin receptor variant (Asp600Asn) in the KK strain. The microsatellite marker D4Mit175, which is closely linked $(0 \cdot 7$ centimorgan $(\mathrm{cM})$ ) with the leptin receptor variant, is associated with obesity in female F2 mice of a $\mathrm{C} 57 \mathrm{BL} / 6 \mathrm{~J} \times \mathrm{KK}$ intercross.

\section{MATERIALS AND METHODS}

\section{Animals}

Inbred mouse strains (C57BLKS/JH1, C57BLKS/ $\mathrm{JHl}-L e p r^{d b} / \operatorname{Lepr}^{d b}, \mathrm{KK} / \mathrm{Hl}$ ) were kept and bred in the Diabetesforschungsinstitut, Düsseldorf. The Principles of Laboratory Animal Care (NIH publication No. 85-23, revised 1985) were followed. All animals were fed a mouse diet containing $21 \%$ protein, $4 \cdot 5 \%$ fat and $51 \%$ of a mixture of carbohydrates (SNIFF, Soest, Germany); they had free access to food and tap water.

At the Jackson laboratory, C57BL/6J females were mated to $\mathrm{KK} / \mathrm{H} 1 \mathrm{Lt}$ males and the $\mathrm{F} 1$ progeny were mated inter se to produce $320 \mathrm{~F} 2$ (intercross) progeny. Litters were reduced to ten pups within 1 week of birth, weaned at 3 weeks, and housed three or four per pen in double-pen plexiglass boxes. Their diet contained $10.4 \%$ fat (primarily from corn oil) and $20.8 \%$ protein (estimated calories from fat, $24 \cdot 5 \%$ ). At 16 weeks of age mice were weighed, fasted overnight and killed. The inguinal, gonadal, retroperitoneal and mesenteric fat pads were dissected and weighed.

\section{Preparation of RNA and cDNA}

Non-fasted animals were killed by decapitation, and subcutaneous, retroperitoneal and gonadal fat pads were dissected. Midbrain sections comprising the hypothalamic area were dissected, and all samples were immediately frozen in liquid nitrogen. Samples of adipose tissue were homogenized with a Polytron homogenizer (Janke \& Kunkel, Staufen i.Br., Germany) in guanidinium thiocyanate (4 M, supplemented with 7\% mercaptoethanol) and RNA was isolated by centrifugation on a cesium chloride cushion $\left(5.88 \mathrm{M} ; 140000 \boldsymbol{g}\right.$ for $29 \mathrm{~h}$ at $20^{\circ} \mathrm{C}$ in an SW40 rotor, Beckman Instruments, Palo Alto, CA, USA). Hypothalamic tissue $(30 \mathrm{mg})$ was homogenized in a Potter-Elvehjem homogenizer and total RNA was isolated with the RNeasy kit from Qiagen
(Hilden, Germany). First strand cDNA was synthesized from total RNA with a kit from Pharmacia (Freiburg, Germany).

\section{Polymerase chain reaction (PCR), rapid amplification of cDNA ends (RACE) and PCR cloning}

The total coding region of the Lep gene was amplified by PCR with primers derived from the published sequence (Zhang et al. 1994, acc. no. U18812) (upstream primer 5'-AAG ATC CCA GGG AGG AAA-3'; reverse primer 5'-CTG GTG GCC TTT GAA ACT-3'). The 5'-untranslated region was amplified by the RACE procedure with a kit from Gibco (Gaithersburg, MD, USA). Eight overlapping cDNA fragments of the leptin receptor b (Tartaglia et al. 1995, Chen et al. 1996, Lee et al. 1996) and the promoter region of the Lep gene (He et al. 1995, de la Brousse et al. 1996) were amplified with primers derived from the published sequences (acc. nos of LepR, U46135 and U49107; acc. nos of Lep promoter, U52147 and S81087; primer sequences on request). PCR products were separated on agarose and subcloned into the SmaI site of pUC19 (Sureclone kit, Pharmacia). Plasmid DNA was prepared and sequenced in both directions. Mismatches were confirmed by a second PCR with cDNA from a different animal.

\section{Primer extension}

Primer extension analysis was performed with a kit from Promega (Madison, WI, USA) with an endlabeled oligonucleotide corresponding to nucleotides 153-178 of the Lep cDNA (acc. no. U18812). Processing of the samples was performed according to the technical bulletin of the manufacturer. A sequencing reaction of the longest $\mathrm{RACE}$ clone with the same oligonucleotide was used as standard for determination of the size of the product.

\section{Northern blot analysis}

Samples of total RNA (15 $\mu \mathrm{g})$ were separated and hybridized as described previously (Igel et al. $1996 a, b)$ with probes generated by random oligonucleotide priming (Feinberg \& Vogelstein 1983).

\section{Preparation of adipose tissue extracts and assay of leptin}

Samples of epididymal or retroperitoneal adipose tissue were homogenized with a Potter-Elvehjem homogenizer in ice-cold lysis buffer $(20 \mathrm{mM}$ Tris, 
pH 7·4, $150 \mathrm{mM}$ sodium chloride, $0 \cdot 2 \mathrm{mM}$ phenylmethylsulfonyl fluoride and $1 \%$ Triton X-100) and were centrifuged for $30 \mathrm{~min}\left(15000 \mathrm{~g}, 4^{\circ} \mathrm{C}\right)$. Specific antiserum $(2.5 \mu \mathrm{l})$ raised against recombinant leptin (Halaas et al. 1995) was added to $250 \mu \mathrm{l}$ lysates ( $1 \mathrm{mg}$ total protein) and the samples were incubated for $2 \mathrm{~h}$ at $4{ }^{\circ} \mathrm{C}$. Immune complexes were adsorbed to protein A-Sepharose (Pharmacia),

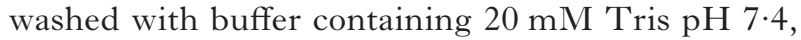
$150 \mathrm{mM}$ sodium chloride and $0 \cdot 1 \%$ Triton X-100 and eluted with Laemmli's sample buffer. The samples were separated by SDS-PAGE and transferred to nitrocellulose membrane (Schleicher and Schuell, Dassel, Germany) with a tank-blot apparatus (Pharmacia). The membranes were blocked overnight by incubation in a buffer containing $10 \mathrm{mM}$ Tris, $\mathrm{pH} 7 \cdot 5,100 \mathrm{mM}$ sodium chloride and $0 \cdot 1 \%$ Tween 20 and were incubated for $2 \mathrm{~h}$ at room temperature with the anti-leptin antiserum at a dilution of 1:100. Washing and detection of bound antibodies with ${ }^{125}$ I-protein A (Amersham-Buchler, Braunschweig, Germany) were performed as previously described (Igel et al. 1996a).

\section{Immunoprecipitation and assay of leptin in serum}

Samples of specific anti-leptin antiserum $(2.5 \mu \mathrm{l})$ were adsorbed to protein A-Sepharose $(100 \mu \mathrm{l}$ packed beads) by an overnight incubation in $250 \mu \mathrm{l} \mathrm{PBS}$. In order to remove $\gamma$-globulins, serum from normal and obese animals was preincubated with protein A-Sepharose. The stripped serum was added to Sepharose beads loaded with specific serum and incubated for $2 \mathrm{~h}$. The beads were separated by centrifugation and were washed three times with PBS. Immunocomplexes were eluted, separated by SDS-PAGE, and probed as described in the preceding paragraph. In some samples leptin was assayed by RIA with a kit from Linco Research (St Charles, MO, USA).

\section{Other assays}

Serum immunoreactive insulin was assayed with RIA kits from Pharmacia. Purified rat insulin (Novo Research Institute, Bagsvaerd, Denmark) was used as standard. Blood glucose was determined by an automated glucose oxidase method (Care Diagnostica, Voerde, Germany).

\section{Analysis of obesity in F2 mice}

DNA was extracted from spleen samples by the phenol-chloroform method, and the microsatellite marker D4Mit175 was typed by PCR as described previously (Taylor \& Phillips 1996). An adiposity index (AI), defined as the sum of all fat pad weights divided by body weight, was used as an overall measure of adiposity. The ratio of specific fat pad weights to body weight was used as an indicator of relative fat pad mass. For merging data of both genders, data from males and females were normalized by subtracting the gender means and dividing by gender-specific standard deviations. The association between D4Mit175 and the different indicators of adiposity was judged by computing likelihood of the odds (lod) scores using Mapmaker quantitative trait locus (QTL) (Lander et al. 1987). Since we wished to test the specific hypothesis that the $L e p r$ variant influenced adiposity, we adopted lod score thresholds appropriate for a single locus test rather than the more stringent threshold applied to genome-wide linkage searches.

\section{RESULTS}

\section{Obesity, hyperglycemia and hyperinsulinemia in the KK strain}

Figure 1 characterizes the KK mice with respect to body weight, hyperinsulinemia and hyperglycemia. Since the genotype of $\mathrm{KK}$ mice is fixed by continuous inbreeding, metabolically normal controls with an identical genetic background are not available. Consequently, we compared KK with obese C57BLKS/J-Lepr $r^{d b} / L_{e p r^{d b}}$ mice and their lean litter mates $(\mathrm{C} 57 \mathrm{BLK} / \mathrm{J}+/+)$. As compared with the lean $\mathrm{KS} / \mathrm{J}$ mice, $\mathrm{KK}$ mice exhibited a significantly higher body weight (Fig. 1). However, obese C57BLKS/J-Lepr $r^{d b} / \operatorname{Lepr}^{d b}$ mice developed a much higher degree of obesity over the period of 4 months. Like KS/J-Lepr $r^{d b}$ mice, KK mice showed elevated glucose and insulin levels (Fig. 1).

\section{Levels of leptin protein in adipose tissue and serum of KK mice}

As we have previously reported (Igel et al. 1996b), mRNA levels of leptin (not shown) were markedly elevated in adipose tissue from KK mice; these levels appeared comparable with those of weightmatched Lepr $r^{d b} / \operatorname{Lepr}^{d b}$ mice. Leptin protein levels were assessed by immunoprecipitation and subsequent immunoblotting of the immunoprecipitates with specific antiserum. As is illustrated in Fig. 2A, the immunoprecipitates from adipose tissue of $\mathrm{KK}$ and $L e p r^{d b} / \operatorname{Lepr}^{d b}$ mice yielded a strong signal at $15 \mathrm{kDa}$. Because of cleavage of the signal sequence (Zhang et al. 1994), this band migrates with a higher electrophoretic mobility than that of 

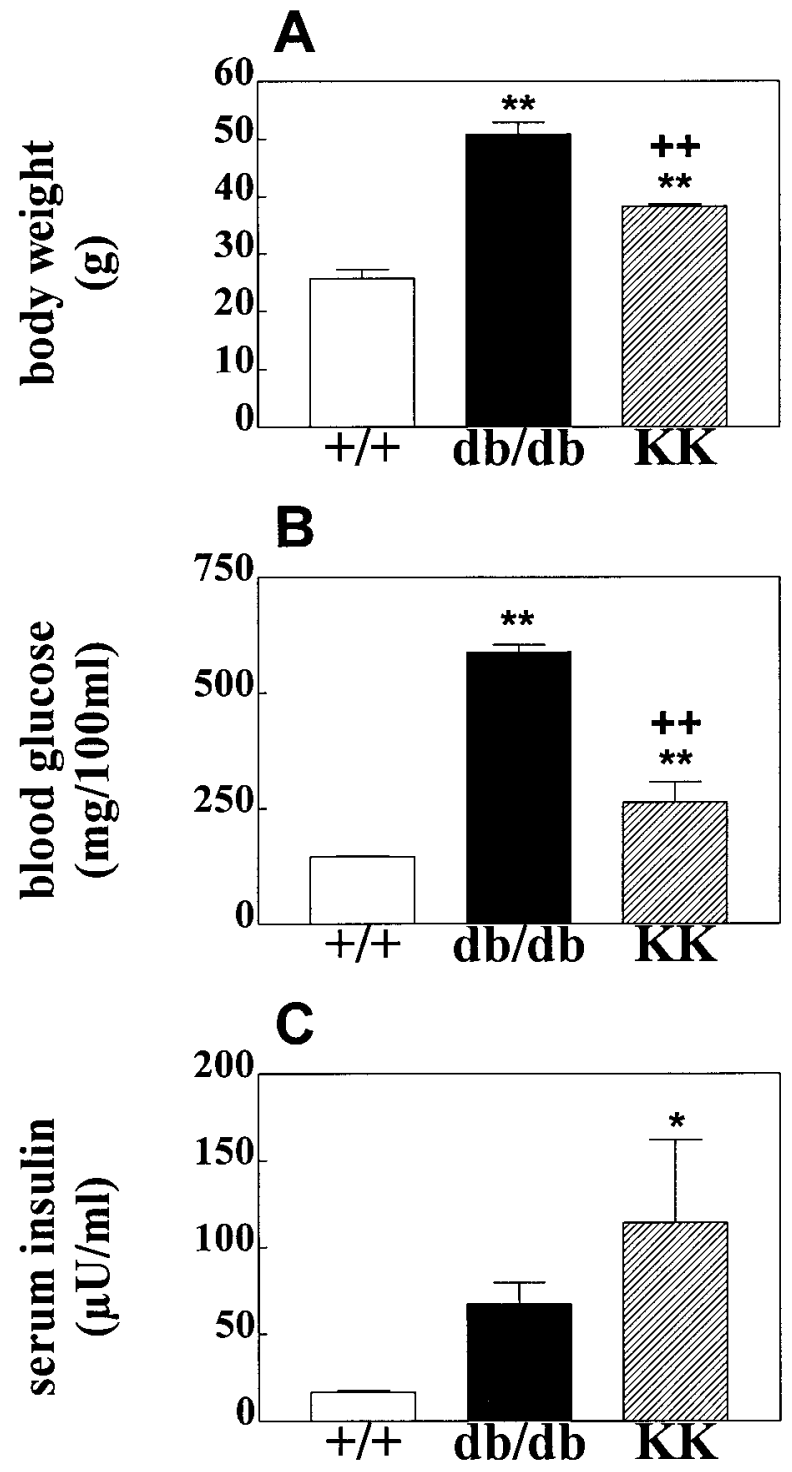

FIGURE 1. Characterization of obesity, hyperglycemia and hyperinsulinemia in KK, C57BLKS/J-Lepr $r^{d b} / L e p r^{d b}$ and C57BLKS/J-+/+ mice. The data are derived from age-matched (4 months) animals and represent means \pm s.E. of three to eight animals. (A) Body weight; (B) blood glucose; (C) serum insulin. Differences between $+/+$ and $L e p r^{d b}$ mice $(\mathrm{db} / \mathrm{db})(* * P<0 \cdot 01$; $\left.{ }^{*} P<0 \cdot 05\right)$ and between KK and $L e p r^{d b}$ mice $\left({ }^{++} P<0 \cdot 01\right)$ were tested for statistical significance by ANOVA.

recombinant leptin $(16 \mathrm{kDa})$. Immunoprecipitates from lean C57BLKS/J-+/+ mice showed a much weaker signal.

Similar results were obtained with immunoprecipitates of serum from the different mouse strains. As is illustrated in Fig. 2B, levels of leptin were elevated in serum of KK mice and in the
A

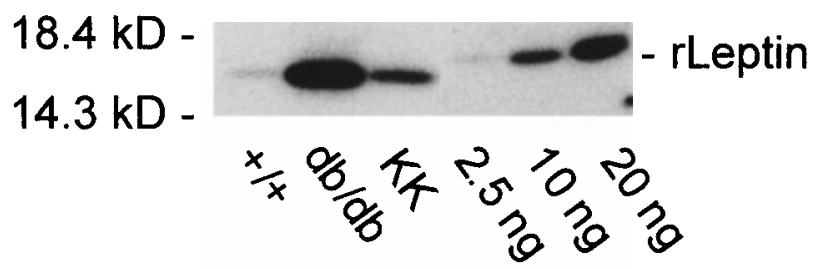

B

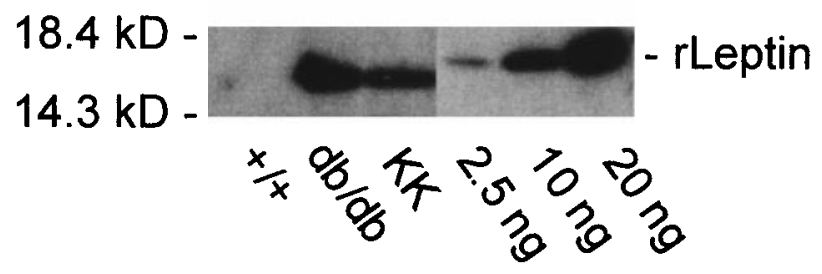

FIGURE 2. Assessment of levels of immunoreactive leptin in adipose tissue and serum of KK, C57BLKS/J$L e p r^{d b} / L_{e p r^{d b}}$ and C57BLKS/J-+/+ mice. (A) Adipose tissue from the indicated animals was homogenized in lysis buffer and leptin was isolated by immunoprecipitation as described. The immunoprecipitates were separated by SDS-PAGE, blotted onto nitrocellulose, and probed with the same antiserum. Bound $\gamma$-globulins were detected with protein A. Standards of recombinant leptin (rLeptin) were run in parallel. Densitometric readings (arbitrary units): $+/+$, $0 \cdot 18 ; \mathrm{db} / \mathrm{db}, 4 \cdot 08 ; \mathrm{KK}, 1 \cdot 25$. (B) Leptin was isolated by immunoprecipitation from serum obtained from the indicated animals and the immunoprecipitates were assayed as in panel A. Densitometric readings: +/+, $0 \cdot 03 ; \mathrm{db} / \mathrm{db}, 3 \cdot 56 ; \mathrm{KK}, 1 \cdot 69$.

$L e p r^{d b} / L e p r^{d b}$ strain. Densitometric analysis of data from a series of age-matched animals $(n=3)$ indicated a 12-fold elevation of leptin in adipose tissue from $\mathrm{KK}$ mice and a 55 -fold increase in $L e p r^{d b} /$ Lepr $^{d b}$ mice (controls (C57BLKS/J-+/+), $0 \cdot 065 \pm 0 \cdot 02 ; \mathrm{KK}, 0 \cdot 78 \pm 0 \cdot 47 ;$ Lepr $^{d b} /$ Lepr $^{d b}, 3 \cdot 61 \pm$ $0 \cdot 1)$. Leptin levels assayed by RIA were also elevated in serum of younger (12-14 weeks) KK mice: controls $(\mathrm{C} 57 \mathrm{BLKS} / \mathrm{J}-+/+$, body weight $24 \cdot 4 \pm 1.6 \mathrm{~g})$, $2 \cdot 1 \pm 0.3 \mathrm{ng} / \mathrm{ml} ; \quad \mathrm{KK}$ (body weight $29 \cdot 2 \pm 1.0 \mathrm{~g}$ ), $7 \cdot 6 \pm 1 \cdot 5 \mathrm{ng} ; P<0 \cdot 01$.

\section{cDNA, transcription start and promoter sequence of the $o b$ gene}

In order to test the possibility that a mutation in the Lep cDNA contributed to the obese phenotype, the coding region was amplified by PCR with mRNA from KK mice. Furthermore, the $5^{\prime}$-untranslated region of the Lep cDNA was isolated by the RACE 
1 GGGACCCGTC CTTAAACTAC CGCTGCTCAG TAGCTGCTGG CCAGACCTCG

51 AGGATTACCG GCTCATACCA AGCGCCCCCA AACTTGCACT CGAGGGCGCG $\mathrm{T}$

101 GCTGAAGTCC TCCCTCGAGG CGCCTAGAAT GGAGCACTAG GTTGCTGCTG

151 CCACTGTTGC TGgCCCGCTG GGTGgGgCGg GAGTTGGCGC TCGCAGGGAC

$$
---\mathrm{C} / \mathrm{EBP}-\cdots
$$

- TATA-

201 TGGgGCTGGC CGGACAgTTG CGCAAGTGGC ACTGGGGCAG TTATAAGAGG

\section{exon 1 \\ 251 GGCAGGCAGg CATGGAGCCC CGgA $\overline{\text { GGGATC CCTGCTCCAG CAGCTGCAAG }}$ \\ $\uparrow$}

301 GTAAGGCCCG GGGCGC

FIGURE 3. Sequence of the $5^{\prime}$-flanking region and transcription initiation site of the Lep gene of KK. The transcription initiation site (vertical arrow) of the Lep gene of KK was determined by RACE and primer extension analysis as described in Materials and Methods. Two nucleotide polymorphisms in the promoter region are highlighted by bold-type letters. The sequence of the remaining $5^{\prime}$-untranslated region and the coding region were determined by RACE and PCR cloning (sequence not shown) and were identical with the reported wild-type sequence.

procedure. The nucleotide sequence of the coding region of the cDNA (not shown) and the 5'-UTR was identical with that of the published wild-type sequence (Zhang et al. 1994). The transcription initiation site of the Lep gene of $\mathrm{KK}$ as deduced from the RACE clones (Fig. 3) and a primer extension experiment (data not shown) was identical with that observed in the C57BL strain (He et al. 1995, de la Brousse et al. 1996).

In order to search for possible nucleotide exchanges in the $5^{\prime}$-flanking region of the Lep gene from KK, a genomic DNA fragment comprising the promoter region was amplified and sequenced. Two nucleotide polymorphisms were found (Fig. 3) upstream from the promoter region, which harbors binding elements for the transcription factors Sp1 and C/EBP (He et al. 1995, de la Brousse et al. 1996).

\section{PCR amplification of leptin receptor isoforms (LeprA and LeprB) and sequence of the leptin receptor (LepRb) cDNA in KK mice}

Hypothalamic tissue from C57BLKS/J-+/+, $L e p r^{d b} / \operatorname{Lepr}^{d b}$ and KK mice was isolated and fragments of the two major splicing variants (LeprA and LeprB) were amplified by reverse transcription PCR. Abundant cDNA from both splicing variants was produced from mRNA of KK mice (not shown), suggesting that mRNA of both isoforms was present and that the leptin resistance in KK mice is not due to absence of the leptin receptor
mRNA. The sequence of the leptin receptor cDNA was determined from eight overlapping fragments generated by PCR with primers deduced from the published LeprB sequence. All fragments were obtained in good yield (not shown). Sequencing of the fragments revealed that the leptin receptor of the KK mouse contained three nucleotide polymorphisms (Table 1), one of them producing a conservative amino acid exchange (Asp600Asn) in the extracellular domain of the leptin receptor. In C57BLKS/J, C57BL/6J, NON and NZO, however, we found the wild-type sequence in codon 600 .

Figure 4 illustrates the location of the Asp600Asn exchange in the leptin receptor. The leptin receptor is a member of the family of class I cytokine

TABLE 1. Nucleotide and amino acid exchanges in the leptin receptor (LeprB) of KK mice. Eight overlapping fragments were generated by PCR with primers deduced from the published sequence. Mismatches were confirmed in a second PCR on cDNA from a different animal. The wild-type sequence of codon 600 (GAC) was found in C57BLKS/J, C57BL/6J, NZO and NON mice

\begin{tabular}{lll} 
Codon no. & $\begin{array}{l}\text { Nucleotide } \\
\text { exchange }\end{array}$ & $\begin{array}{l}\text { Amino acid } \\
\text { exchange }\end{array}$ \\
$\begin{array}{ll}584 \\
600\end{array}$ & $\mathrm{CAT} \rightarrow \mathrm{CAC}$ & - \\
1072 & $\mathrm{GAC} \rightarrow \mathrm{AAC}$ & $\mathrm{D} \rightarrow \mathrm{N}$ \\
& $\mathrm{GAG} \rightarrow \mathrm{GAA}$ & - \\
\hline
\end{tabular}




\begin{abstract}
gP130 248 GLGGLLDLKSDIQYRTKDASTWIQV-PLEDTMSPRTSFTVQDLKPF--TEYVFRIRSIKDSGKGYWSDWSEEAST hLepR 256 SWSSPPLVPFPLQYQVKYSENSTTVIREADKIVSATSLLVDSILPG--SSYEVQVRGKRLDGPGIWSDWSTPRVF $r L$ LepR 255 SWDSQTMAPFPLQYQVKYLENSTIV-REAAEIVSDTSLIVNSVLPG--SSYEVQVRSKRLDGSGVWSDWSLPQVG mLepR 255 SWDSQTMAPFPLQYQVKYLENSTIV-REAAEIVSATSLLVDSVLPG--SSYEVQVRSKRLDGSGVWSDWSSPQVG $\mathrm{fa} / \mathrm{fa}: \mathrm{P}$
\end{abstract}

hLepR 557 SWEKPVFPENNLQFQIRYGLSGKEVQWKMYEVYDAKSKSVSLPVPDLCAVYAVQVRCKRLDGLGYWSNWSNPAYT rLepR 555 SWEKPVFPENNLQFQIRYGLNGKEIQWKTHEVFDAKSKSASLLVSDLCAVYVVQVRCRRLDGLGYWSNWSSPAYT mLepR 555 SWEKPVFPENNLQFQIRYGLSGKEIQWKTHEVFDAKSKSASLLVSDLCAVYVVQVRCRRLDGLGYWSNWSSPAYT KK: $\mathbf{N}$

FIGURE 4. Alignment of the conserved parts of CRHMs in gp130 and leptin receptors and position of point mutations in the $f a / f a$ and KK strains. The CRHM which was defined by Bazan (1990) is involved in the interaction of gp130 with the IL-6 receptor (gp80) and contains motifs conserved in all cytokine receptors. This module is found twice in the extracellular part of the leptin receptor. The point mutations found in Zucker rats and KK mice are given underneath the alignments. Residues conserved in all sequences are highlighted by bold-type letters; the aspartate residues corresponding with the mutated residue of KK are highlighted by italics.

receptors and contains two extracellular cytokinereceptor homology modules (CRHM), which are presumably involved in ligand binding and homoor heterodimerization (Kishimoto et al. 1994). Molecular modeling of the Lepr (not shown) on the basis of a model of its closest relative, gp130, suggested that Asp600 is located in a loop presumably contacting a second, interacting receptor molecule. Note that the Lepr ${ }^{f a} / L_{e p r}{ }^{f a}$ mutation which is responsible for the obese, insulin-resistant phenotype of the Zucker rat (Chua et al. 1996b, Phillips et al. 1996) is located in the vicinity of the conserved aspartate residue in the first CRHM of Lepr (Fig. 4).

\section{QTL analysis of the microsatellite marker D4Mit175 in an intercross of KK and C57BL/6J mice}

In order to assess the contribution of the Lepr mutation of $\mathrm{KK}$ for the obese phenotype, the F2 generation of a cross of $\mathrm{KK}$ mice with the lean C57BL/6J (B6) strain was genotyped for the microsatellite marker D4Mit175, which maps approximately $0 \cdot 7 \mathrm{cM}$ proximal to Lepr (Chua et al. $1996 a)$. Because of this close linkage, and because the parental strains are homozygous for alternative alleles at both Lepr and D4Mit175, typing the F2 progeny for the latter marker is essentially equivalent to genotyping for the Asp600Asn polymorphism. Lod scores were computed for gender-merged data, and for males and females separately. As is shown in Table 2, results for the two genders were quite different. No association was apparent between the parameters of obesity and the marker in male F2 progeny. However, in females a nearly significant lod score (1.77) was obtained for AI, with increased adiposity associated with the presence of the KK allele. This falls just below the 1.8 threshold appropriate for testing a single trait in gender-split data. Substantial lod scores were also obtained for the percentage

TABLE 2. QTL analysis of a $(\mathrm{B} 6 \times \mathrm{KK}) \mathrm{F} 2$ cross for the microsatellite marker D4Mit175. F2 hybrids $(n=320)$ of a cross of B6 $\times$ KK were genotyped for the marker D4Mit175. Traits analyzed include adiposity index (AI), and inguinal (ING), gonadal (GON), retroperitoneal (RET) and mesenteric (MES) fat pad weight, expressed as percentages of body weight. The lod scores were obtained with Mapmaker QTL software, using the free genetics option

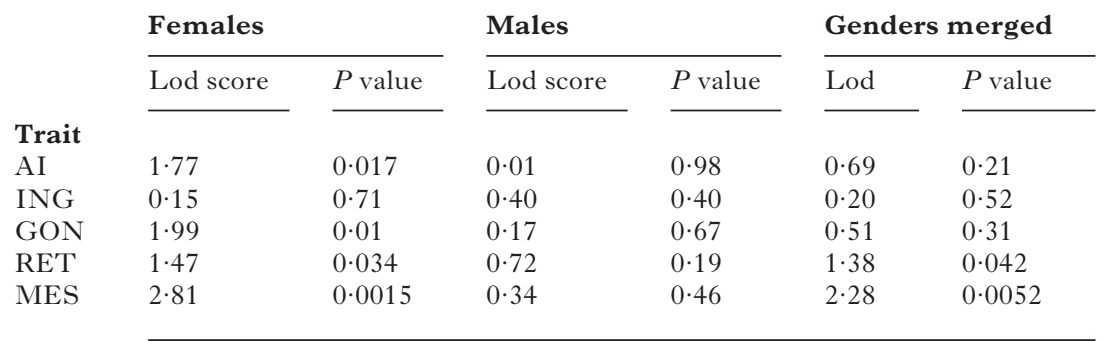

The lod score threshold of significance $(P<0 \cdot 05)$ for the gender merged data in a two-sided Chi square test is $1 \cdot 3$. For gender-split association tests, the appropriate threshold is $1 \cdot 8$. $P$ values shown here are not adjusted for analysis of multiple traits. 
contributions of retroperitoneal (1.47), gonadal $(1 \cdot 99)$ and mesenteric $(2 \cdot 81)$, but not inguinal $(0 \cdot 15)$ fat pads to overall body weight. Because the four individual fat pad traits are quasi-independent, but completely predict AI, a conservative adjusted $P$ value for judging the significance of the individual fat pad traits is $0 \cdot 0125(=0 \cdot 05 / 4)$, corresponding to a Chi square (2 degrees of freedom) criterion of $8 \cdot 77$. This Chi square value corresponds to a lod score of $2 \cdot 4(=(8 \cdot 77 / 4 \cdot 6)+0 \cdot 5)$. (The divisor $4 \cdot 6$ converts a Chi square statistic to a lod score statistic.) By this stringent criterion, only the lod score associated with female mesenteric fat pad weight $(2 \cdot 81)$ attains significance. Overall, however, the data suggest that the Lepr allele of $\mathrm{KK}$ contributes to obesity in the females, especially to mesenteric fat pad weight.

Analysis with Mapmaker QTL provides estimates of the degree of dominance of putative QTL alleles. Female heterozygotes for D4Mit175 were intermediate between the $\mathrm{KK}$ and $\mathrm{C} 57 \mathrm{BL} / 6$ homozygotes for mesenteric fat percentage and other obesity related traits, indicating a lack of genetic dominance.

\section{DISCUSSION}

The present data indicate that the KK allele of a polymorphic microsatellite marker near the leptin receptor gene (D4Mit175) is weakly linked to obesity in female $\mathrm{F} 2$ of a $\mathrm{KK} \times \mathrm{B} 6$ cross. Since obesity in $\mathrm{KK}$ mice is a multigenic trait, a single locus cannot be the only basis of the syndrome. Accordingly, the lod score of the linkage is close to the threshold of significance, and is insignificant in the male F2 mice. The gender-specific association may help account for the higher degree of obesity in F2 females of the cross (AI in males, $10 \cdot 9 \pm 0 \cdot 2$; females, $16 \cdot 2 \pm 0 \cdot 4$ ). Presumably, hormonal factors partially protect males from multigenic obesity in this cross. The D4Mit175 locus was not linked with inguinal fat weight, and there appeared to be differential effects at the other sites of adipose deposition, with the strongest effect on mesenteric fat accumulation. In fact, in the known leptin $\left(L e p^{o b} / L e p^{o b}\right)$ and leptin receptor $\left(L e p r^{d b} / L e p r^{d b}\right)$ mutants, the accumulation of fat appears to be much more pronounced in the abdomen than in subcutaneous tissue. However, males and females appear to be equally affected by these loss-offunction mutations.

We suggest here that the association between D4Mit175 and adiposity reflects the contribution of the Asp600Asn Lepr variant. D4Mit175 is in full linkage disequilibrium $(0.7 \mathrm{cM})$ with $L e p r$. Thus, it is safe to conclude that the association between
D4Mit175 and adiposity is essentially identical with that between $L e p r$ and adiposity. It cannot fully be excluded, however, that some other gene linked to D4Mit175 and Lepr contributed to obesity. In fact, an obesity QTL, dietary obesity 1 (Dob1), which segregates in a cross between strains $\mathrm{AKR} / \mathrm{J}$ and SWR/J, maps about $10 \mathrm{cM}$ distal to D 4 Mit 175 (West et al. 1994). Thus, further analysis is needed to test the possibility that Dob1 or some other gene linked to D4Mit175 contributes to obesity in the KK strain.

The Asp/Asn exchange in Lepr of $\mathrm{KK}$ is considered a conservative substitution, which exchanges a carboxyl group for its amide. Asp600 is conserved in all known species homologs of the leptin receptor, and also in all other mouse strains we tested (C57BL/6J, C57BLKS/J, NON, NZO). The extracellular part of Lepr contains two cytokine-receptor modules, each consisting of two domains. The first domain is characterized by four conserved cysteine residues, the second by the conserved WSXWS motif. The Asp600Asn substitution is located in the second CRHM close to the WSXWS motif. The CRHMs are believed to interact with the ligands of the class I cytokine receptors and/or with subunits of the receptors (Bazan 1990, Kishimoto et al. 1994). Molecular modeling of the Lepr on the basis of the structure of gp130, the next relative of the leptin receptor, indicated that Asp600 is located in an outward facing loop. In gp130, this loop is believed to be in contact with the interleukin (IL)-6 binding subunit of the receptor (gp80) which is required for activation of the Jak/signal transducer and activator of transcription (STAT) pathway (Savino et al. 1994, Grötzinger et al. 1997). Since leptin receptors appear to form dimers after ligand binding (White et al. 1997a), it is conceivable that interaction of the two receptor molecules and their signal transduction are affected in the Asp600Asn variant. Thus, the location of Asp600 and its conservation in both CRHMs support the assumption that its exchange may alter the function of the receptor.

The phenotype of the fatty Zucker rat $(f a / f a)$ is caused by a mutation in a conserved motif of the first CRHM (Gln269Pro) (Phillips et al. 1996). The functional consequence of this mutation has not yet been fully elucidated. The Gln269Pro exchange reduces leptin receptor binding to cells overexpressing the mutant (Chua et al. 1996b). Surprisingly, it is the receptor number and not their affinity which is reduced in cells overexpressing the mutant. Furthermore, the intracellular signaling (STAT5B activation) appears to be impaired by the Gln269Pro exchange in the extracellular CRHM of the $f a / f a$ Lepr variant (White et al. 1997b). Thus, 
it cannot be predicted whether the Asp600Asn exchange affects the ligand binding of the receptor, its signaling, or its processing to the plasma membrane. Furthermore, since genotyping of the $\mathrm{C} 57 \mathrm{BL} / 6 \mathrm{~J} \times \mathrm{KK}$ intercross has shown that the effect of the Asp600Asn variant on obesity is small, it may be difficult to detect alterations of ligand binding or receptor signaling in an in vivo system of transfected cells.

Two nucleotide exchanges were found in the 5 '-flanking region of the KK Lep gene. These polymorphisms are outside the known regulatory elements of the promoter $(\mathrm{C} / \mathrm{EBP} \alpha$ binding site), but one of them is within the 217 nucleotides of the $5^{\prime}$ sequence which are required for full basal and stimulated promoter activity (Miller et al. 1996). Thus, it cannot fully be excluded that the nucleotide polymorphisms affect the function of the Lep promoter. However, we found that the levels of leptin mRNA, immunoreactive protein in adipose tissue and serum leptin were reasonably well correlated with the degree of obesity of the KK mouse. Thus, there is no clear indication that the polymorphisms in the Lep gene contribute to the obese phenotype by a reduction of serum leptin.

\section{ACKNOWLEDGEMENTS}

The sequences reported in this paper have been submitted to the GenBank/EMBL Data Bank with acc. nos Y10296 and Y10297. The skilful technical assistance of Ms Angela Schraven and Susanne Breitwieser is gratefully acknowledged. Advice on statistical analysis was provided by Drs Ariel Darvasi and Gary Churchill, a molecular model of Lepr was generated by Joachim Grötzinger. This study was supported by the Deutsche Forschungsgemeinschaft (JO117/11-1), the Bundesministerium für Bildung, Forschung und Technologie and NIH grant DK50692 from the National Institute of Diabetes, Digestive and Kidney Diseases. Core grant CA34196 from the National Cancer Institute supported several shared services of The Jackson Laboratory.

\section{REFERENCES}

Bazan JF 1990 Structural design and molecular evolution of a cytokine receptor superfamily. Proceedings of the National Academy of Sciences of the USA 87 6934-6938.

de la Brousse FC, Shan B \& Chen J-L 1996 Identification of the promoter of the mouse obese gene. Proceedings of the National Academy of Sciences of the USA 93 4096-4101.

Campfield LA, Smith FJ, Guisez Y, Devos R \& Burn P 1995 Recombinant mouse ob protein: evidence for a peripheral signal linking adiposity and central neural networks. Science $269546-549$.

Campfield LA, Smith FJ \& Burn P 1996 The OB protein pathway - a link between adipose tissue mass and central neural networks. Hormone and Metabolic Research 28 619-632.

Chen H, Charlat O, Tartaglia LA, Woolf EA, Weng X, Ellis SJ, Lakey ND, Culpepper J, Moore KJ, Breitbart RE, Duyk GM, Tepper RI \& Morgenstern JP 1996 Evidence that the diabetes gene encodes the leptin receptor: identification of a mutation in the leptin receptor gene in $d b / d b$ mice. Cell $\mathbf{8 4}$ 491-495.

Chua SC, Chung WK, Wu-Peng XS, Zhang Y, Liu SM, Tartaglia LA \& Leibel RL $1996 a$ Phenotypes of mouse diabetes and rat fatty due to mutations in the OB (leptin) receptor. Science 271 994-996.

Chua SC, White DW, Wu-Peng XS, Liu SM, Okada N, Kershaw EE, Chung WK, Power-Kehoe L, Chua M, Tartaglia LA \& Leibel RL $1996 b$ Phenotype of fatty due to Gln269Pro mutation in the leptin receptor. Diabetes $\mathbf{4 5}$ 1141-1143.

Feinberg AP \& Vogelstein B 1983 A technique for radiolabeling DNA restriction endonuclease fragments to high specific activity. Analytical Biochemistry 132 6-13.

Friedman JM 1997 The alphabet of weight control. Nature 385 119-120.

Grötzinger J, Kurapkat G, Wollmer A, Kalai M \& Rose-John S 1997 The family of the IL-6-type cytokines: specificity and promiscuity of the receptor complexes. Proteins 27 96-109.

Halaas JL, Gajiwala KS, Maffei M, Cohen SL, Chait BT, Rabinowitz D, Lallone RL, Burley SK \& Friedman JM 1995 Weight-reducing effects of the plasma protein encoded by the obese gene. Science $269543-546$.

He Y, Chen H, Quon MJ \& Reitman M 1995 The mouse obese gene: genomic organization, promoter activity, and activation by CCAAT/enhancer binding protein. Fournal of Biological Chemistry 270 28887-28891.

Herberg L \& Coleman DL 1977 Laboratory animals exhibiting obesity and diabetes syndromes. Metabolism 26 59-98.

Igel M, Becker W, Herberg L \& Joost HG $1996 a$ Evidence that reduced leptin levels, but not an aberrant sequence of leptin or its receptor, contribute to the obesity syndrome in NON mice. Hormone and Metabolic Research 28 669-674.

Igel M, Kainulainen H, Brauers A, Becker W, Herberg L \& Joost HG $1996 b$ Long-term and rapid regulation of $o b$ mRNA levels in adipose tissue from normal (Sprague Dawley rats) and obese ( $d b / d b$ mice, $f a / f a$ rats) rodents. Diabetologia 39 758-765.

Igel M, Becker W, Herberg L \& Joost HG 1997 Hyperleptinemia, leptin resistance and polymorphic leptin receptor in the New Zealand Obese mouse. Endocrinology 138 4234-4239.

Kishimoto T, Taga T \& Akira S 1994 Cytokine signal transduction. Cell 76 253-262.

Kondo K, Nozawa K, Tomita T \& Ezaki K 1957 Inbred strains resulting from Japanese mice. Bulletin of the Experimental Animals 6 107-112.

Lander ES, Green P, Abrahamson J, Barlow A, Daly MJ, Lincoln SE \& Newburg L 1987 MAPMAKER: an interactive computer package for constructing primary genetic linkage maps of experimental and natural populations. Genomics 1 174-181.

Lee GH, Proenca R, Montez JM, Carroll KM, Darvishzadeh JG, Lee JI \& Friedman JM 1996 Abnormal splicing of the leptin receptor in diabetic mice. Nature $\mathbf{3 7 9}$ 632-635. 
Maffei M, Fei H, Lee GH, Dani C, Leroy P, Zhang Y, Proenca R, Negrel R, Ailhaud G \& Friedman JM 1995 Increased expression in adipocytes of $o b$ RNA in mice with lesions of the hypothalamus and with mutations at the $d b$ locus. Proceedings of the National Academy of Sciences of the USA 92 6957-6960.

Miller SG, de Vos P, Guerre-Millo M, Wong K, Hermann T, Staels B, Briggs MR \& Auwerx J 1996 The adipocyte specific transcription factor $\mathrm{C} / \mathrm{EBP} \alpha$ modulates human ob gene expression. Proceedings of the National Academy of Sciences of the USA 93 5507-5511.

Murakami T \& Shima K 1995 Cloning of rat obese cDNA and its expression in obese rats. Biochemical and Biophysical Research Communications 209 944-952.

Nakamura M \& Yamada K 1967 Studies on a diabetic (KK) strain of mice. Diabetologia 3 212-221.

Pelleymounter MA, Cullen MJ, Baker MB, Hecht R, Winters D, Boone T \& Collins F 1995 Effects of the obese gene product on body weight regulation in $o b / o b$ mice. Science 269 540-543.

Phillips MS, Liu Q, Hammond HA, Dugan V, Hey PJ, Caskey CT \& Hess JF 1996 Leptin receptor missense mutation in the fatty Zucker rat. Nature Genetics 13 18-19.

Savino R, Lahm A, Salvati AL, Ciapponi L, Sporeno E, Altamura S, Painessa G, Toniatti C \& Ciliberto G 1994 Generation of interleukin-6 receptor antagonists by molecular modeling guided mutagenesis of residues important for gp130 activation. EMBO Fournal 13 1357-1367.
Tartaglia LA, Dembski M, Weng X, Deng N, Culpepper J, Devos R, Richards GJ, Campfield LA, Clark FT, Deeds J, Muir C, Sanker S, Moriarty A, Moore KJ, Smutko JS, Mays GG, Woolf EA, Monroe CA \& Tepper RI 1995 Identification and expression cloning of a leptin receptor, OB-R. Cell 83 1263-1271.

Taylor BA \& Phillips SJ 1996 Detection of obesity QTLs on mouse chromosomes 1 and 7 by selective DNA pooling. Genomics 34 389-398.

West DB, Waguespack J, York B, Goudey-Lefevre J \& Price RA 1994 Genetics of dietary obesity in AKR/J $\times$ SWR/J mice: segregation of the trait and identification of a linked locus on chromosome 4. Mammalian Genome 5 546-552.

White DW, Kuropatwinsky KK, Devos R, Baumann H \& Tartaglia LA 1997a Leptin receptor signaling: cytoplasmic domain mutational analysis and evidence for receptor homo-oligomerization. Fournal of Biological Chemistry 272 4065-4071.

White DW, Wang DW, Chua SC, Morgenstern JP, Leibel RL, Baumann H \& Tartaglia LA $1997 b$ Constitutive and impaired signaling of leptin receptors containing the Gln/Pro extracellular domain fatty mutation. Proceedings of the National Academy of Sciences of the USA 94 10657-10662.

Zhang Y, Proenca R, Maffei M, Barone M, Leopols L \& Friedman JM 1994 Positional cloning of the mouse obese gene and its human homologue. Nature 372 425-432.

RECEIVED 20 March 1998 